\title{
Relationships among superantigen toxin gene profiles, genotypes, and pathogenic characteristics of Staphylococcus aureus isolates from bovine mastitis
}

\author{
Dong Wang, ${ }^{*}$ Limei Zhang, $†$ Changfu Yong,ł Mingliang Shen,§ Tariq Ali,† Muhammad Shahid,† Kun Han,\# \\ Xuezhang Zhou, ${ }^{*}$ and Bo Hant ${ }^{1}$ \\ *Key Laboratory of the Ministry of Education for the Conservation and Utilization of Special Biological Resources of Western China, \\ College of Life Science, Ningxia University, Yinchuan, Ningxia 750021, China \\ †College of Veterinary Medicine, China Agricultural University, Beijing 100193, China \\ $\ddagger$ Animal Disease Control and Prevention Center of Shapotou District, Zhongwei, Ningxia 755000, China \\ $\S$ Agriculture and Animal Husbandry Bureau of Shizuishan, Shizuishan, Ningxia 753000, China \\ \#Ningxia Center for Disease Control and Prevention, Yinchuan, Ningxia 750004, China
}

\begin{abstract}
Staphylococcus aureus is one of the major etiological agents of bovine mastitis, harboring a wide variety of staphylococcal superantigen $(\mathrm{SAg})$ toxin genes. The $\mathrm{SAg}$ toxin genes are reported to be closely associated with the pathogenicity of the Staph. aureus causing the bovine mastitis. This study was conducted to investigate SAg toxin gene profiles and to assess the relationships among SAg toxin genes, genotypes of Staph. aureus, and their pathogenic properties. A total of 327 quarter milk samples were collected from bovine mastitis cases for isolation and identification of pathogens. In total, 35 isolates were identified as Staph. aureus, and the prevalence of Staph. aureus in milk samples was $13.6 \%(35 / 256)$. Polymerase chain reaction (PCR) and randomly amplified polymorphic DNA (RAPD) assays were used to detect the SAg toxin genes and to genotype Staph. aureus strains isolated from milk samples of bovine mastitis in 10 dairy herds located in Ningxia, China, respectively. The results showed that among the Staph. aureus isolates $(\mathrm{n}=35), 71.4 \%(\mathrm{n}=$ $25)$ of isolates carried at least one SAg toxin gene. In total, $18 \mathrm{SAg}$ genes and 21 different gene combination patterns were detected among these isolates. The most common SAg genes in Staph. aureus isolates were sei, sen, and seu (44.0\% each), followed by seo, tst, and et $B$ (28.0\% each), etA (24.0\%), sem and sep (16.0\% each), seb, sec, sed, and sek (12.0\% each), and sea and seh genes $(8.0 \%$ each); the seg, sej, and ser genes were present in $4.0 \%$ of the isolates. Three gene combinations were found to be related to mobile genetic elements that carried 2 or more genes. The egc-cluster of the
\end{abstract}

Received December 6, 2016.

Accepted February 7, 2017.

${ }^{1}$ Corresponding author: hanbo@cau.edu.cn seg-sei-sem-sen-seo genes, located on the pathogenicity island Type I vSa $\beta$, was detected in $16 \%$ of isolates. Interestingly, we observed 6 RAPD genotypes (I to VI) in Staph. aureus isolates, and 2 of these genotypes were strongly associated with the severity of bovine mastitis; there was a close relationship between the RAPD genotypes and SAg genes. Isolates of RAPD type III were more frequently associated with clinical and subclinical mastitis, whereas strains of type VI were mostly related to subclinical mastitis. In addition, SAg genes were related to severity of bovine mastitis. We conclude that an obvious relationship exists among RAPD genotypes, SAg toxin genes, and severity of bovine mastitis.

Key words: Staphylococcus aureus, bovine mastitis, superantigen toxin genes, PCR

\section{INTRODUCTION}

Staphylococcus aureus is a global pathogen causing several serious diseases in humans and animals. This microorganism is also one of the most common etiological agents of bovine mastitis, which results in huge economic losses to the dairy industry due to the reduced milk quality and production (Deb et al., 2013; Gomes and Henriques, 2016). Importantly, the enterotoxins produced by Staph. aureus are common causes of food poisoning globally (Li et al., 2015; Sabouni et al., 2014). Staphylococcus aureus has a strong capability to produce a wide variety of enterotoxins, including toxic shock syndrome toxin 1 (TSST-1), Panton-Valentine leukocidin (PVL), exfoliative toxins A and B (ETA and ETB), and staphylococcal enterotoxins (SE) including classical enterotoxins (SEA to SEE) with proven emetic activity and newly described enterotoxins, such as staphylococcal-like proteins (SEIL, SEIQ, SEG to SER) without emetic activity. To date, 23 serologically different staphylococcal enterotoxin and staphylococ- 
cal-like proteins have been recognized (Pinheiro et al., 2015; Podkowik et al., 2016). Collectively, these toxins are known as staphylococcal superantigens (SAg) because of their superantigenic activity. These SAg toxin genes have been reported to be associated with the virulence factors in bovine IMI, and these toxins may have an important role in the pathogenesis of bovine mastitis (Aman and Adhikari, 2014; Reyes-Robles et al., 2016). Recent studies have reported that SAg toxin genes are associated with mobile genetic elements such as plasmids, pathogenicity islands, and prophages, suggesting the horizontal transfer of these genes among the bacteria (Malachowa and DeLeo, 2010; Alibayov et al., 2014). In addition, staphylococcal food poisoning, resulting from the consumption of contaminated food with staphylococcal enterotoxins, is one of the most common food-borne illnesses (Suzuki et al., 2015; Corredor Arias et al., 2016).

Considerable genetic heterogeneity in natural populations of Staph. aureus has been documented, and a small number of clonal types not only cause the majority of bovine IMI but also have a wide geographical distribution (Silva et al., 2013; Lundberg et al., 2014). As different pathogenic properties of the pathogens require different strategies toward the prevention and treatment of the disease, research on the genotypes of Staph. aureus causing bovine IMI and their pathogenic properties is of particular clinical importance.

Although a large number of virulence factors have been found in Staph. aureus isolates from bovine IMI, very few studies have investigated the relationships between subtypes of Staph. aureus isolates from bovine IMI and their pathogenic properties. Thus, the present study was carried out to determine SAg toxin genes profiles and randomly amplified polymorphic DNA (RAPD) genotypes of Staph. aureus isolates and to analyze the relationships among SAg toxin genes, genotypes, and pathogenic characteristics of Staph. aureus isolates from bovine mastitis in the dairy herds of Ningxia province of China.

\section{MATERIALS AND METHODS}

\section{Bacterial Isolates}

Previously isolated Staph. aureus isolates $(\mathrm{n}=35)$ from cases of bovine mastitis (Wang et al., 2016) were used in the present study. A total of 327 quarter milk samples were collected from cows with clinical and subclinical mastitis between March and October 2013, which came from 10 herds in 4 geographic regions (Yinchuan, Wuzhong, Shizuishan, and Zhongwei) of Ningxia province (Figure 1), located in northwest China. The majority of cows in the study herds were Chinese Holstein and were housed in freestall barns with straw, sawdust, or sand as bedding. The average size of the herds was 253 cows, and their average yield was 8,540 $\mathrm{kg}$ of milk per lactation. A total of 2,527 cows were involved in the epidemiological investigation of bovine mastitis. Among them, healthy cows accounted for $50.3 \%(1,272 / 2,527)$, the prevalence of clinical mastitis was $13.2 \%(333 / 2,527)$, and the incidence of subclinical mastitis at the cow and quarter level were $36.5 \%$ $(922 / 2,527)$ and $17.8 \%(1,794 / 10,108)$, respectively. Bacterial isolates were identified based on morphological, biochemical, and molecular methods as described previously (Wang et al., 2016). Briefly, after incubation on blood agar, the isolates produced grayish-white or yellow colonies with distinct zones of hemolysis. They were gram-positive cocci and produced catalase, coagulase, and DNase. All the isolates were confirmed by using the PCR amplification of $16 \mathrm{~S}$ rRNA gene specific to Staph. aureus.

\section{DNA Isolation and Purification}

Each Staph. aureus isolate was grown overnight at $37^{\circ} \mathrm{C}$ in brain heart infusion broth (Oxoid, Basingstoke, UK). The genomic DNA of the isolate was extracted and purified using TIANamp Bacteria DNA Kit (Tiangen Biotech, Beijing, China) according to the manufacturer's instruction.

\section{Detection of SAg Toxin Genes}

The presence of genes encoding enterotoxins (se), TSST-1(tst), Panton-Valentine leukocidin $(P V L)$, and exfoliative toxins (etA and etB) in the entire set of Staph. aureus isolates $(\mathrm{n}=35)$ was tested by PCR assays. The SAg toxin genes, primer sequences, and the expected size of PCR products are shown in Table 1. The reaction mixture $(25 \mu \mathrm{L})$ for each PCR contained $50 \mathrm{ng}$ of genomic DNA, 20 pmol of each primer, and $12.5 \mu \mathrm{L}$ of $2 \times$ Taq PCR MasterMix (Tiangen Biotech). Amplification was carried out with the following cycling conditions: a predenaturation step at $94^{\circ} \mathrm{C}$ for $3 \mathrm{~min}$, followed by 30 cycles of amplification (denaturation at $94^{\circ} \mathrm{C}$ for $30 \mathrm{~s}$, annealing for $30 \mathrm{~s}$ at specific temperature, and extension at $72^{\circ} \mathrm{C}$ for $1 \mathrm{~min}$ ), and ending with a final extension at $72^{\circ} \mathrm{C}$ for $5 \mathrm{~min}$. All PCR-amplified products were characterized by $0.8 \%$ agarose gel electrophoresis in $1 \times$ Tris-acetate-EDTA buffer, followed by staining with Gel Red and visualization under UV light. The Staph. aureus strain ATCC29213 was used as the positive control and the negative control (only sterile water) was used in each PCR reaction. 


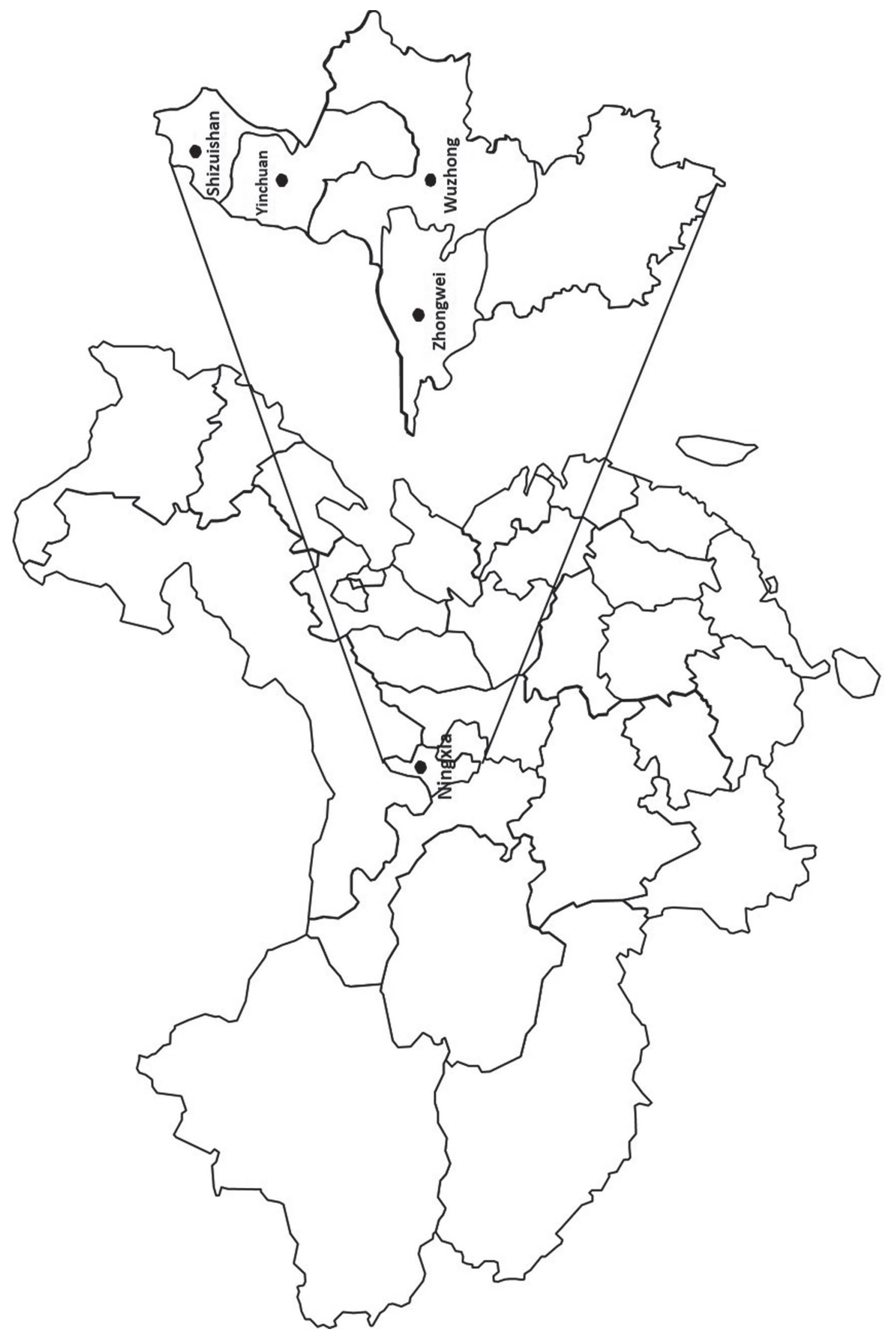


Table 1. The primers for PCR amplification of staphylococcal superantigen (SAg) toxin genes in Staphylococcus aureus isolates

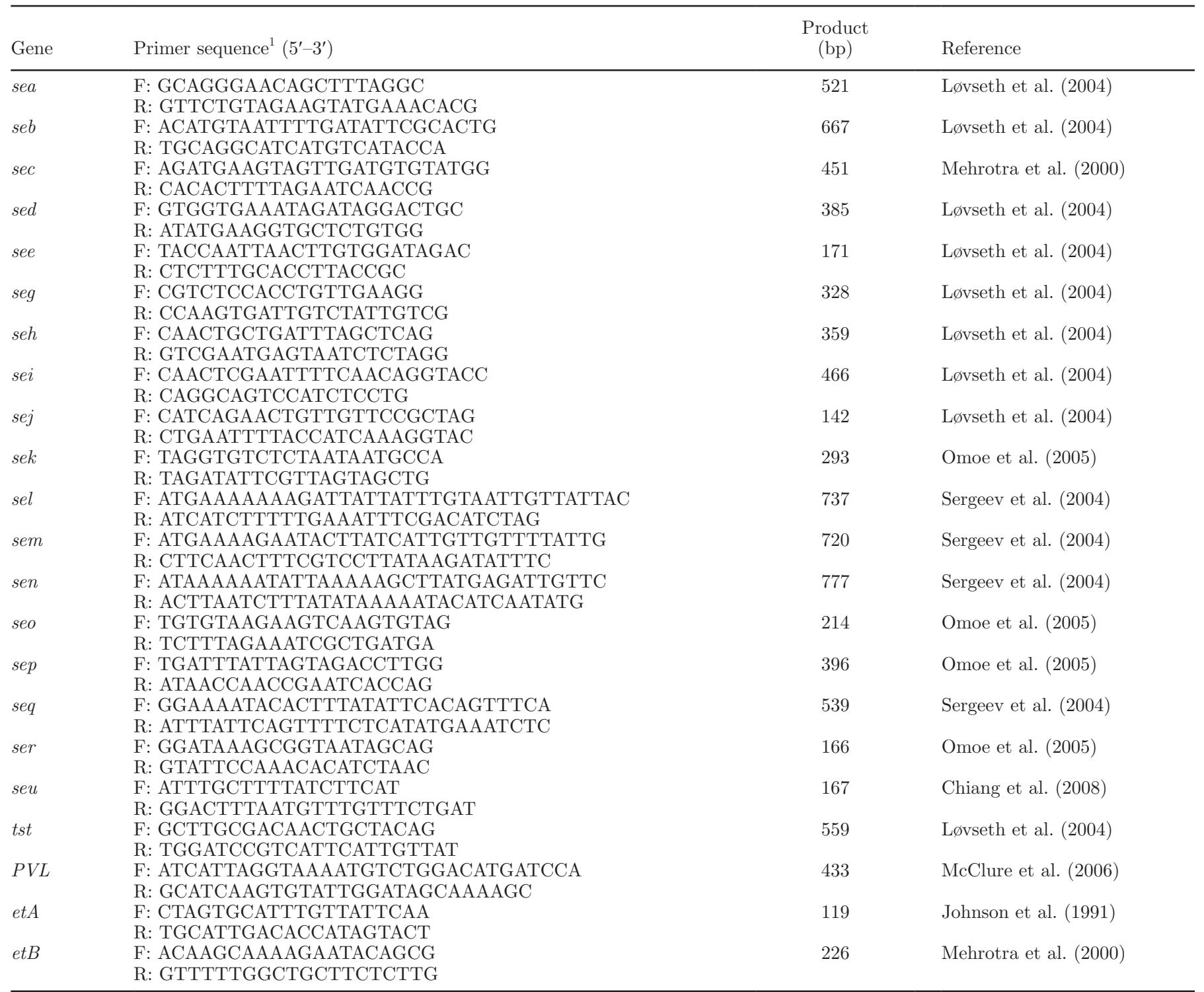

${ }^{1} \mathrm{~F}=$ forward; $\mathrm{R}=$ reverse.

\section{RAPD-Based Genotyping of Staph. aureus Isolates}

A PCR-based RAPD analysis was carried out for the genotyping of all the Staph. aureus isolates as described in our previous study (Wang et al., 2016).

\section{Relationship Between Genotypes, SAg Genes of Staph. aureus, and Severity of Bovine Mastitis}

Bovine mastitis was clinically categorized into clinical and subclinical mastitis based on clinical signs of the disease. Clinical mastitis was defined as the presence of visible abnormalities in the milk (such as watery milk, clots or flakes) and observation of abnormal changes in the udder such as swelling, pain, or heat (Ahmady and Kazemi, 2013; Artursson et al., 2016). Subclinical mastitis was diagnosed when the SCC was greater than 200,000 cells/mL in the milk with little or no overt changes in the milk or udder (Xu et al., 2015; Aslantas and Demir, 2016). The SAg toxin genes and RAPD genotypes of Staph. aureus isolates were co-related to the severity of bovine mastitis in terms of epidemiological and clinical data from 10 herds. 


\section{RESULTS}

\section{Prevalence of SAg Toxin Genes in Staph. aureus Isolates}

The presence of $22 \mathrm{SAg}$ genes in Staph. aureus isolates was tested by PCR assay, as shown in Table 2. Among the 35 Staph. aureus isolates, 25 (71.4\%) harbored at least one SAg gene. A total of $18 \mathrm{SAg}$ toxin genes were detected in these isolates; however, see, sel, seq, and $P V L$ genes were not detected (Figure 2a and b). The most common SAg genes in the Staph. aureus isolates were sei, sen, and seu $(44.0 \%$ each), whereas seo, tst, and etB $(28.0 \%$ each $)$ and et $A(24.0 \%)$ genes were carried by approximately one-fourth of the isolates. The sem and sep genes were PCR amplified in $16.0 \%$ of the isolates, whereas seb, sec, sed, and sek were detected in $12.0 \%$ of the isolates. The sea and seh genes $(8.0 \%$ each) and seg, sej, and ser genes (4.0\% each) were present only within a few isolates (Table 2).

\section{Genotyping of SAg Toxin Genes in Staph. aureus Isolates}

Twenty-one different combinations of toxin genes were detected in 25 Staph. aureus isolates positive for $\mathrm{SAg}$ toxin genes. Genotypes carrying the gene pattern sei-sen-selu were identified in $2(8.0 \%)$ isolates; the et $A$ gene was found in $2(8.0 \%)$ isolates, and $3(12.0 \%)$ isolates were found positive for etB, whereas the other genes were confirmed only in individual strains (Table

Table 2. Prevalence of staphylococcal superantigen (SAg) toxin genes in Staphylococcus aureus isolates $(\mathrm{n}=25)$

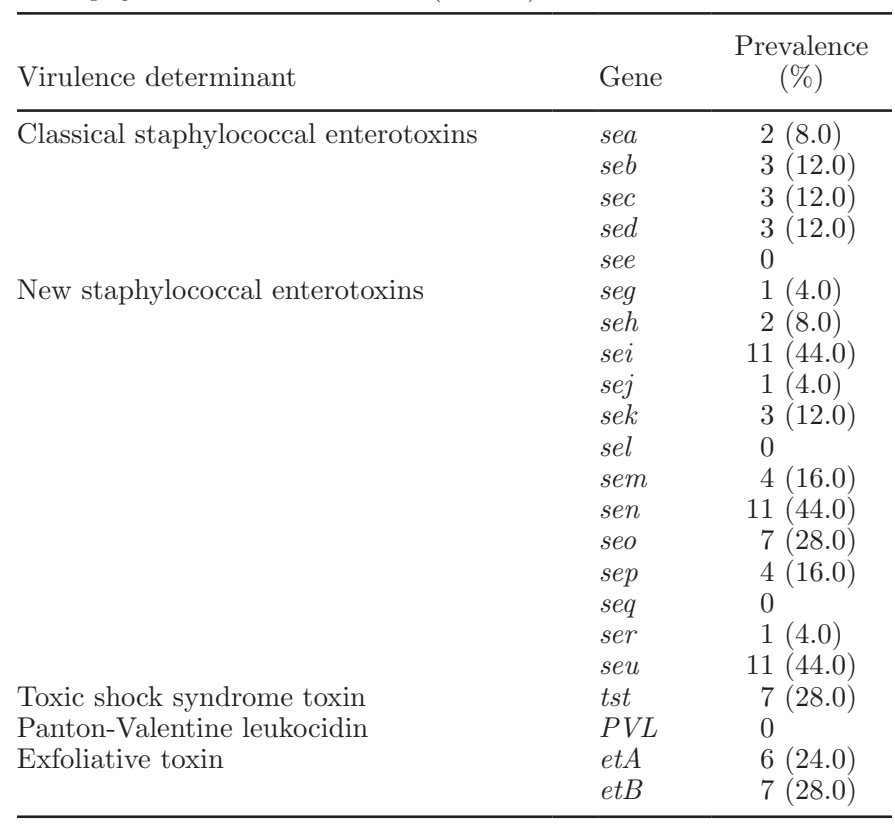
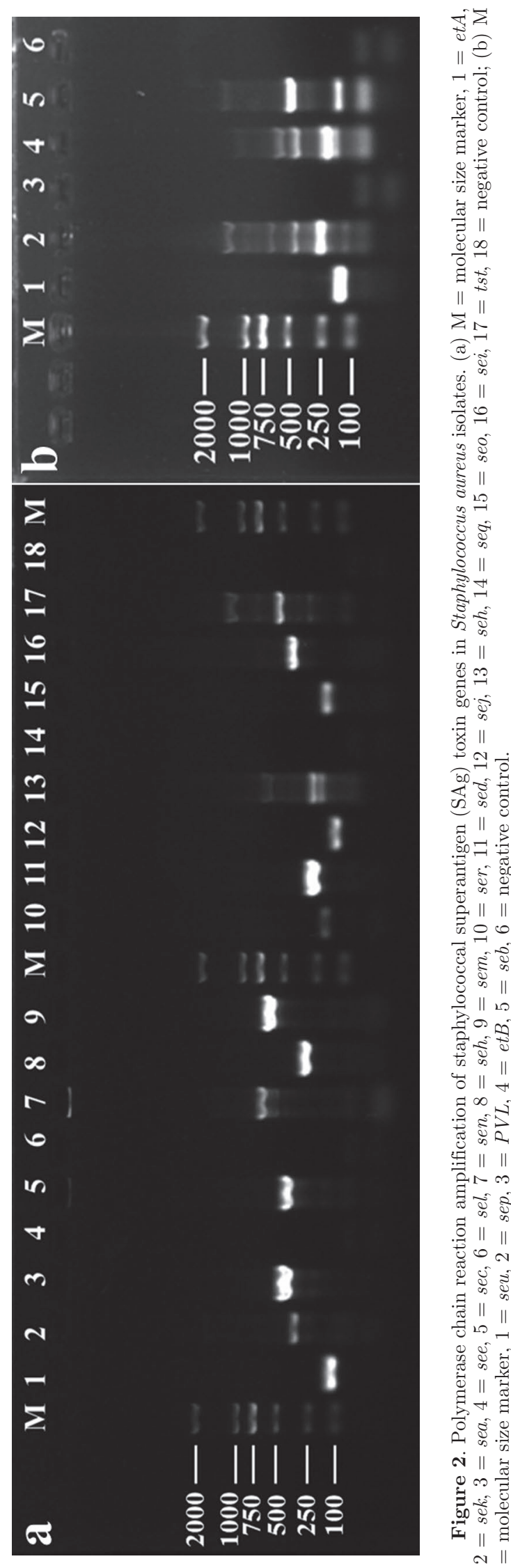

Journal of Dairy Science Vol. 100 No. 6, 2017 
Table 3. The staphylococcal superantigen (SAg) toxin genotypes in Staphylococcus aureus isolates $(\mathrm{n}=25)$

\begin{tabular}{|c|c|c|}
\hline SAg toxin gene pattern & $\begin{array}{c}\text { Prevalence } \\
(\%)\end{array}$ & $\begin{array}{l}\text { Mobile genetic } \\
\text { elements }\end{array}$ \\
\hline Classical staphylococcus enterotoxin (SE) genes & 0 & \\
\hline Classical and new SE genes & $8(32.0)$ & \\
\hline sed, sei, sem, sen, seo, seu, sep, tst, etB & $1(4.0)$ & Type IvSa $\beta, \phi$ Sa3n \\
\hline sed, sei, sem, sen, seo, seu, sep, tst & $1(4.0)$ & Type IvSa $\beta, \phi \operatorname{Sa} 3 n$ \\
\hline sea, sei, sem, sen, seo, seu, tst & $1(4.0)$ & $\phi$ Sa3mu, Type IvSa $\beta$ \\
\hline sea, seg, sei, sen, seu & $1(4.0)$ & $\phi \mathrm{Sa} 3 \mathrm{mu}$ \\
\hline seb, sec, seh, etA & $1(4.0)$ & \\
\hline seb, sec, eta & $1(4.0)$ & \\
\hline seb, sek, sec, et $A$ & $1(4.0)$ & vSa1(SaPI3) \\
\hline sed, sep & $1(4.0)$ & $\phi \mathrm{Sa} 3 \mathrm{n}$ \\
\hline New SE genes & $12(48.0)$ & \\
\hline sei, sem, sen, seo, seu, tst & $1(4.0)$ & Type IvSa $\beta$ \\
\hline sei, sen, seo, seu, tst, etB & $1(4.0)$ & \\
\hline sen, seu, sep, etB & $1(4.0)$ & $\phi \operatorname{Sa} 3 \mathrm{n}$ \\
\hline sek, sei, sen, seo, seu, tst, etA & $1(4.0)$ & \\
\hline sei, sen, seu & $2(8.0)$ & \\
\hline seh, sek, tst & $1(4.0)$ & \\
\hline sej, ser & $1(4.0)$ & $\mathrm{pF} 5$ \\
\hline sei, et $B$ & $1(4.0)$ & \\
\hline sei, seu & $1(4.0)$ & \\
\hline sen & $1(4.0)$ & \\
\hline seo & $1(4.0)$ & \\
\hline Other toxin genes & $5(20.0)$ & \\
\hline etA & $2(8.0)$ & \\
\hline et $B$ & $3(12.0)$ & \\
\hline
\end{tabular}

3). Interestingly, 8 (32.0\%) Staph. aureus isolates contained both classical and new staphylococcal enterotoxin genes, whereas $12(48.0 \%)$ isolates carried only new staphylococcal enterotoxin genes. Five (20.0\%) isolates were positive for et $A$ and et $B$ genes; however, isolates harboring only classical staphylococcal enterotoxin genes were absent.

\section{SAg Toxin Genotypes and Mobile Genetic Elements}

Three gene combinations related to mobile genetic elements, which contained 2 or more SAg toxin genes, were detected (Table 3). The egc-cluster of the seg-seisem-sen-seo genes, being located on the pathogenicity island Type I vSaß, was detected in $16.0 \%$ of the Staph. aureus isolates that lacked the seg gene. The seb-selkselq gene combination, located in the vSa1(SaPI3) pathogenicity island, was carried by $4.0 \%$ of the isolates without the seq gene. Additionally, the sej-ser gene combination located on the same plasmid (pF5) was present in $4.0 \%$ of the isolates. The sea gene existing in the phage $\phi \mathrm{Sa} 3 \mathrm{mu}$ was detected in $8.0 \%$ of the isolates, and the sep gene, related to phage $\phi \mathrm{Sa} 3 \mathrm{n}$, was found in $16.0 \%$ of the Staph. aureus isolates.

\section{RAPD Genotypes and Severity of Bovine Mastitis}

Based on PCR-based RAPD analyses, the 35 Staph. aureus strains isolated from bovine IMI were grouped into 6 RAPD genotypes (Table 4). Epidemiological data regarding bovine mastitis were obtained from the herds from which quarter milk samples were collected. The 35 Staph. aureus strains isolated from milk samples were categorized into subclinical and clinical mastitis based on clinical symptoms of the disease (Table 4). The prevalence of Staph. aureus strains belonging to RAPD type III $(80.0 \%)$ was much higher than that of the RAPD type IV (20.0\%) in clinical mastitis; thus, RAPD type III strains were more frequently associated with clinical mastitis. In contrast, RAPD type VI (40.0\%) and type III (30.0\%) strains were more frequently related to subclinical mastitis.

Table 4. The relationship between randomly amplified polymorphic DNA (RAPD) genotypes and the severity of bovine mastitis in Staphylococcus aureus isolates $(\mathrm{n}=35)$ from bovine mastitis

\begin{tabular}{lccc}
\hline & & \multicolumn{2}{c}{ Severity } \\
\cline { 3 - 4 } RAPD & & $\begin{array}{c}\text { Clinical } \\
\text { genotype }\end{array}$ & $\begin{array}{c}\text { Subclinical } \\
(\%)\end{array}$ \\
\hline I & $(\%)$ & & $3(10.0)$ \\
II & $3(8.6)$ & & $1(3.3)$ \\
III & $1(2.9)$ & & $9(30.0)$ \\
IV & $13(37.1)$ & $1(20.0)$ & $1(3.3)$ \\
V & $2(5.7)$ & & $4(13.3)$ \\
VI & $4(11.4)$ & & $12(40.0)$ \\
Total & $12(34.3)$ & $5(100)$ & $30(100)$ \\
\hline
\end{tabular}


Table 5. The relationship between randomly amplified polymorphic DNA (RAPD) genotypes and staphylococcal superantigen (SAg) toxin genes in clinical Staphylococcus aureus isolates $(\mathrm{n}=25)$

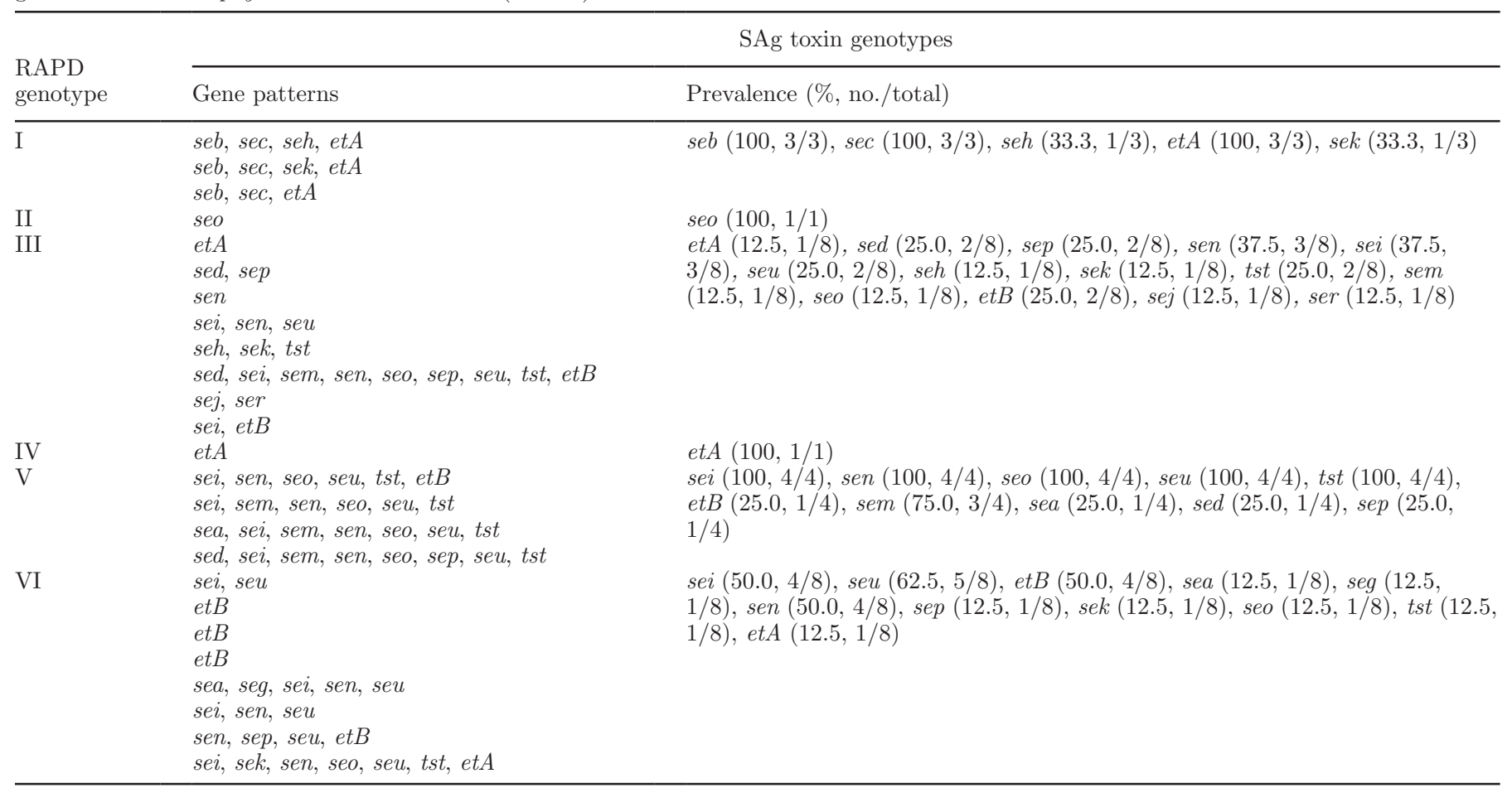

\section{Association of RAPD Genotypes with SAg Toxin Genes}

We assessed the association of RAPD genotypes with SAg toxin genes in the Staph. aureus strains and the results are shown in Table 5. In 3 clinical Staph. aureus isolates of RAPD genotype I and that harbored 3 gene patterns with 5 genes in tandem, all of the isolates were positive for seb, sec, and etA genes (100\% each); therefore, the $s e b, s e c$, and et $A$ genes were more frequently associated with RAPD genotype I. In addition, 8 isolates were found to be associated with RAPD genotype III with 8 genes patterns that carried 14 genes. In these Staph. aureus isolates, the sei and sen genes were present in $37.5 \%$ of the isolates; thus, these genes were more frequently associated with RAPD genotype III. The RAPD genotype $\mathrm{V}$ with 4 genes patterns, carrying 10 genes in tandem, was related to 4 Staph. aureus isolates. All of these Staph. aureus isolates contained the sei, sen, seo, seu, and tst genes (100\% each), and $75 \%$ of the isolates carried the sem gene; thus, the sei, sen, seo, seu, sem, and tst genes were more frequently associated with the RAPD genotype V. Moreover, 8 Staph. aureus isolates were found to be related to RAPD genotype VI, exhibiting 8 genes patterns with 11 genes. Among these Staph. aureus, $62.5 \%$ of the isolates carried the seu gene, and half of the isolates possessed the sei, sen and $e t B$ genes; therefore, the seu, sei, sen, and $e t B$ genes were more frequently related to RAPD genotype VI.

\section{SAg Toxin Genotypes and Severity of Bovine Mastitis}

As shown above, Staph. aureus isolates with RAPD genotype III were more frequently associated with clinical mastitis, whereas isolates with RAPD genotypes VI and III were predominantly related to subclinical mastitis (Table 4). The sei and sen genes were more frequently related to RAPD genotype III, whereas the seu, sei, sen, and etB genes were more frequently related to RAPD genotype IV (Table 5). Therefore, we can conclude that the sei and sen genes were more frequently related to clinical mastitis, and the seu, sei, sen, and et $B$ genes were mostly related to subclinical mastitis (Table 6).

\section{DISCUSSION}

Staphylococcus aureus is a pathogen that causes several serious diseases in both humans and animals worldwide. This organism has the capacity to produce a variety of enterotoxins, collectively known as SAg. In the present study, we found that among 35 Staph. aureus strains isolated from milk samples of bovine mas- 
titis cases in Ningxia province of China, $71.4 \%$ of the isolates harbored at least one of the $\mathrm{SAg}$ genes. These findings were in accordance with the reports from Italy (Vimercati et al., 2006) and Japan (Katsuda et al., 2005). However, these results are slightly contradicted by the study of Karahan et al. (2009), in which it was reported that $30 \%$ of Staph. aureus isolates were positive for staphylococcal enterotoxin-encoding genes in Turkey. Up to 92.6 and $95.0 \%$ of Staph. aureus isolates contained at least one SAg gene in Belgium (Ote et al., 2011) and Switzerland (Fournier et al., 2008), respectively. These discrepancies may reflect the considerable variation in the prevalence of the staphylococcal enterotoxin-encoding genes among different geographical locations (Oliveira et al., 2011; Artursson et al., 2016). It is worth noting that approximately three-fourths of the Staph. aureus isolates tested in the current study carried one or several SAg toxin-encoding genes, which may indicate that Staph. aureus associated with IMI might pose a high risk for human health due to the presence of these SAg toxins genes in milk; therefore, considerable attention should be paid to the food safety of dairy products.

In this study, all Staph. aureus isolates tested negative for see, which is in agreement with other studies conducted in Belgium (Ote et al., 2011), China (Xu et al., 2015), and Switzerland (Fournier et al., 2008). None of the isolates tested contained the seq gene, which is in concordance with the study conducted in Spain (Fueyo et al., 2005). The present study demonstrated that the distribution of different SAg genes in Staph. aureus isolates was highly heterogeneous, which coincided with the recent studies from Belgium (Ote et al., 2011) and Australia (McMillan et al., 2016).

It is well established that the pathogenicity of Staph. aureus strains relies on their repertoire of virulence factors. It has been documented that SAg toxin genes are related to mobile genetic elements, including pathogenicity islands, prophages, and plasmids (Malachowa and DeLeo, 2010; Alibayov et al., 2014), which may suggest that SAg toxin genes can be transferred horizontally between staphylococcal strains. It is commonly observed that Staph. aureus strains hold more than one staphylococcal enterotoxin gene (Fijałkowski et al., 2014; Dunyach-Remy et al., 2016). In the present study, some gene combinations related to mobile genetic elements (consisting of 2 or more SAg toxin genes) were detected.

The egc-cluster located on the pathogenicity island Type I vSa $\beta$, carrying the seg-sei-sem-sen-seo gene pattern, was detected in $16.0 \%$ of the Staph. aureus isolates, which was detected less frequently than in previous studies. In a study conducted in Belgium, the egc-cluster was found in $31.4 \%$ of Staph. aureus isolates (Ote et al., 2011), and in a study in Spain (Fueyo et al., $2005), 45.2 \%$ of the isolates contained the egc-cluster. In addition, the egc-cluster found without 1 ( seg) or 2 (sem and seo or seg and sem) genes in the present study. Similarly, the study of Omoe et al. (2005) also demonstrated the egc-cluster lacking 1 (seo) or 2 (sem and sen) genes.

The gene cluster harboring sec, tst, and sel genes is located on the pathogenicity island SaPIbov (Fournier et al., 2008). In a Spanish study, the cluster of tst, sec, and sel was found in $13.1 \%$ of isolates (Fueyo et al., 2005); however, in the current study, the cluster of sec, tst, and sel genes was not detected in any isolate. The sel gene was not amplified by PCR in any of the Staph. aureus isolates in the current study, and the sec and tst genes were detected separately. The sec gene was detected in $12 \%$ of the Staph. aureus isolates, whereas the tst gene was harbored by $28.8 \%$ of the isolates, a finding compatible with the study in Belgium (Ote et al., 2011) but higher than the data reported from some other countries (Karahan et al., 2009; Piccinini et al., 2010).

Similar to other findings, in our study the seb-selkselq gene combinations without the $s e q$ gene, which was located on the uSa1 (SaPI3) pathogenicity island, was tested. The sej-ser gene combination present on the

Table 6. The relationship between staphylococcal superantigen (SAg) toxin genotypes of Staphylococcus aureus isolates $(\mathrm{n}=25)$ and the severity of bovine mastitis

\begin{tabular}{|c|c|c|c|}
\hline \multirow{2}{*}{$\begin{array}{l}\mathrm{RAPD}^{1} \\
\text { genotype }\end{array}$} & \multirow{2}{*}{$\begin{array}{l}\text { Major SAg toxin } \\
\text { genotypes detected }\end{array}$} & \multicolumn{2}{|c|}{ Types of mastitis } \\
\hline & & Clinical (\%) & Subclinical (\%) \\
\hline I & $s e b, s e c$, et $A$ & & $3(10.0)$ \\
\hline II & seo & & $1(3.3)$ \\
\hline III & sei, sen & $4(80.0)$ & $9(30.0)$ \\
\hline IV & etA & $1(20.0)$ & $1(3.3)$ \\
\hline V & sei, sem, sen, seo, seu, tst & & $4(13.3)$ \\
\hline VI & sei, sen, seu, etB & & $12(40.0)$ \\
\hline Total & & $5(100)$ & $30(100)$ \\
\hline
\end{tabular}

${ }^{1}$ Randomly amplified polymorphic DNA. 
plasmid (pF5) was found; the sea gene in the phage $\phi \mathrm{Sa} 3 \mathrm{mu}$ was detected; the sep gene located on the phage $\phi$ Sa3n was identified; and seh gene present in the antibiotic resistance staphylococcal cassette chromosome mec (SCCmec) was detected (Omoe et al., 2005; Nazari et al., 2014; Xu et al., 2015).

The exfoliative toxins A and B are related to staphylococcal scalded-skin syndrome (Handler and Schwartz, 2014). In the current study, et $A$ was found in $24 \%$ of Staph. aureus isolates and etB was discovered in $28 \%$ of the isolates, in contrast to other reports. Although the et $A$ gene was detected in $18.3 \%$ of the isolates in Belgium, other studies from Europe showed that none of the Staph. aureus isolates recovered from bovine IMI harbored et $A$ and etB (Piccinini et al., 2010; Ote et al., 2011). In a recent Chinese study, all of the 28 Staph. aureus isolated from subclinical mastitis were negative for both the $e t A$ and $e t B$ genes (Xu et al., 2015).

Panton-Valentine leucocidin (PVL) is encoded by 2 cotranscribed genes, lukS-PV and lukF-PV (lukS/F$P V)$, which are located on a prophage and cause leukocyte destruction and tissue necrosis (Bhatta et al., 2016). The presence of PVL-encoding genes in Staph. aureus is reported to be associated with increased disease severity (Shariati et al., 2016). In the present study, none of the Staph. aureus isolate carried the $l u k S / F-P V$ genes, which was in accordance with studies reported from Spain (Fueyo et al., 2005) and Italy (Parisi et al., 2016); in contrast, $0.4 \%$ of the Staph. aureus isolates were positive for both $l u k S-P V$ and $l u k F-P V$ genes in Belgium (Ote et al., 2011).

Notably, a close relationship is reported between genotypes of Staph. aureus and the severity of bovine mastitis. The epidemiological data on 92 Staph. aureus strains isolated from cows in Ireland indicated that RAPD type VII and RAPD type V isolates were more likely to be linked to clinical mastitis (Fitzgerald et al., 2000). In Switzerland, genotype B was confirmed to be associated with high contagiousness and increased pathogenicity, whereas the other types $(\mathrm{C}, \mathrm{OG})$ were found to be related to IMI of single cows (Fournier et al., 2008). In the current study, RAPD type III strains was more frequently associated with clinical mastitis, whereas RAPD types VI and III strains were more frequently related to subclinical infections; therefore, we concluded that genotypes of Staph. aureus are strongly associated with the severity of the bovine mastitis.

Furthermore, a strong association has been documented between RAPD type and SEC/TSST-1 production among Irish Staph. aureus isolates from cows with IMI (Fitzgerald et al., 2000). In Ireland, $87.5 \%$ of the RAPD type VII isolates coproduced TSST- 1 and SEC, and $16 \%$ of the tested isolates from Irish herds produced TSST-1. In Switzerland, genotypes B and C were clearly different in their virulence gene patterns. Genotype B was related to sed (84\%), sej (80\%), and sea $(77 \%)$ genes, whereas genotype $\mathrm{C}$ was related to seg $(100 \%)$, sec $(61 \%)$, and tst $(61 \%$; Fournier et al., 2008). In the present study, our results suggested that RAPD type $\mathrm{V}$ was strongly associated with the tst gene. Among RAPD type V strains, all isolates (100\%) were positive for the tst gene; however, none of these isolates contained the sec gene. Among 35 Staph. aureus isolates from bovine mastitis cases, $20 \%$ of the isolates were positive for the tst gene. In addition, our findings demonstrated that the seb, sec, and etA genes $(100 \%$ each) were associated with RAPD type I; sei and sen genes $(37.5 \%$ each) were related to RAPD type III; and seu $(62.5 \%)$, sei, sen, and etB genes (50.0\% each) were related to RAPD type VI; therefore, this might suggest a close relationship between genotypes of Staph. aureus and SAg toxin genes.

In the current study, RAPD type III strains (80.0\%) were associated with clinical mastitis, whereas RAPD types VI (40.0\%) and III strains (30.0\%) were related to subclinical infections. The sei and sen genes $(37.5 \%$ each) were related to RAPD type III, whereas the seu $(62.5 \%)$, sei, sen, and $e t B$ genes $(50.0 \%$ each) were related to RAPD type IV; therefore, we conclude that the sei and sen genes were more frequently related to clinical mastitis, and the seu, sei, sen, and et $B$ genes were more frequently related to subclinical mastitis. The results of the present study strongly supported the conclusion that SAg toxin genotypes are related to the severity of bovine mastitis.

\section{CONCLUSIONS}

Our results indicate that a relationship exists among RAPD genotypes, $\mathrm{SAg}$ toxin genes, and severity of bovine mastitis. The findings of the present work revealed that the genotypes of Staph. aureus strains isolated from bovine mastitis cases in Ningxia, China, were closely related to $\mathrm{SAg}$ toxin gene patterns and pathogenic characteristics of the pathogens.

\section{ACKNOWLEDGMENTS}

This research was financially supported by the major innovation project in science, engineering, and agriculture of the first-class university of Western China, Ningxia University (no. 20170301), Ningxia Science and Technology Support Project (no. 2013), the Chinese thirteen "Five-year" National Science and Technology Support Project (no. 2016YFD0501203), Ministry of Education in China major project (No. 313054), and 
the National Natural Science Foundation of China (no. 31572587 and no. 3151101034). The authors declare that they have no competing interest.

\section{REFERENCES}

Ahmady, M., and S. Kazemi. 2013. Detection of the enterotoxigenic genes (sei,sej) in Staphylococcus aureus isolates from bovine mastitis milk in the West Azerbaijan of Iran. Comp. Clin. Pathol. 22:649-654. https://doi.org/10.1007/s00580-012-1460-3.

Alibayov, B., L. Baba-Moussa, H. Sina, K. Zdeňková, and K. Demnerová. 2014. Staphylococcus aureus mobile genetic elements. Mol. Biol. Rep. 41:5005-5018. https://doi.org/10.1007/s11033-0143367-3.

Aman, M. J., and R. P. Adhikari. 2014. Staphylococcal bicomponent pore-forming toxins: targets for prophylaxis and immunotherapy. Toxins (Basel) 6:950-972. https://doi.org/10.3390/toxins6030950.

Artursson, K., R. Söderlund, L. Liu, S. Monecke, and J. Schelin. 2016. Genotyping of Staphylococcus aureus in bovine mastitis and correlation to phenotypic characteristics. Vet. Microbiol. 193:156-161. https://doi.org/10.1016/j.vetmic.2016.08.012.

Aslantas, O.., and C. Demir. 2016. Investigation of the antibiotic resistance and biofilm-forming ability of Staphylococcus aureus from subclinical bovine mastitis cases. J. Dairy Sci. 99:8607-8613. https://doi.org/10.3168/jds.2016-11310.

Bhatta, D. R., L. M. Cavaco, G. Nath, K. Kumar, A. Gaur, S. Gokhale, and D. R. Bhatta. 2016. Association of Panton Valentine leukocidin (PVL) genes with methicillin-resistant Staphylococcus aureus (MRSA) in Western Nepal: A matter of concern for community infections (a hospital based prospective study). BMC Infect. Dis. 16:199. https://doi.org/10.1186/s12879-016-1531-1.

Chiang, Y. C., W. W. Liao, C. M. Fan, W. Y. Pai, C. S. Chiou, and H. Y. Tsen. 2008. PCR detection of staphylococcal enterotoxins (SEs) $\mathrm{N}, \mathrm{O}, \mathrm{P}, \mathrm{Q}, \mathrm{R}, \mathrm{U}$, and survey of SE types in Staphylococcus aureus isolates from food-poisoning cases in Taiwan. Int. J. Food Microbiol. 121:66-73. https://doi.org/10.1016/j.ijfoodmicro.2007.10.005.

Corredor Arias, L. F., J. S. Luligo Espinal, J. I. Moncayo Ortiz, J. J. Santacruz Ibarra, and A. Álvarez Aldana. 2016. Relationship between super antigenicity, antimicrobial resistance and origin of Staphylococcus aureus isolated. Colomb. Med. 47:15-20.

Deb, R., A. Kumar, S. Chakraborty, A. K. Verma, R. Tiwari, K. Dhama, U. Singh, and S. Kumar. 2013. Trends in diagnosis and control of bovine mastitis: A review. Pak. J. Biol. Sci. 16:16531661.

Dunyach-Remy, C., C. Ngba Essebe, A. Sotto, and J.-P. Lavigne. 2016. Staphylococcus aureus toxins and diabetic foot ulcers: Role in pathogenesis and interest in diagnosis. Toxins (Basel) 8:E209. https://doi.org/10.3390/toxins8070209.

Fijałkowski, K., M. Struk, J. Karakulska, A. Paszkowska, S. GiedrysKalemba, H. Masiuk, D. Czernomysy-Furowicz, and P. Nawrotek. 2014. Comparative analysis of superantigen genes in Staphylococcus xylosus and Staphylococcus aureus isolates collected from a single mammary quarter of cows with mastitis. J. Microbiol. 52:366-372. https://doi.org/10.1007/s12275-014-3436-2.

Fitzgerald, J. R., P. J. Hartigan, W. J. Meaney, and C. J. Smyth. 2000. Molecular population and virulence factor analysis of Staphylococcus aureus from bovine intramammary infection. J. Appl. Microbiol. 88:1028-1037.

Fournier, C., P. Kuhnert, J. Frey, R. Miserez, M. Kirchhofer, T. Kaufmann, A. Steiner, and H. U. Graber. 2008. Bovine Staphylococcus aureus: Association of virulence genes, genotypes and clinical outcome. Res. Vet. Sci. 85:439-448. https://doi.org/10.1016/j. rvsc.2008.01.010.

Fueyo, J. M., M. C. Mendoza, M. R. Rodicio, J. Muñiz, M. A. Alvarez, and M. C. Martín. 2005. Cytotoxin and pyrogenic toxin superantigen gene profiles of Staphylococcus aureus associated with subclinical mastitis in dairy cows and relationships with macrorestriction genomic profiles. J. Clin. Microbiol. 43:1278-1284. https://doi. org/10.1128/JCM.43.3.1278-1284.2005.
Gomes, F., and M. Henriques. 2016. Control of bovine mastitis: Old and recent therapeutic approaches. Curr. Microbiol. 72:377-382. https://doi.org/10.1007/s00284-015-0958-8.

Handler, M. Z., and R. A. Schwartz. 2014. Staphylococcal scalded skin syndrome: Diagnosis and management in children and adults. J. Eur. Acad. Dermatol. Venereol. 28:1418-1423. https://doi. org $/ 10.1111 /$ jdv. 12541

Johnson, W. M., S. D. Tyler, E. P. Ewan, F. E. Ashton, D. R. Pollard, and K. R. Rozee. 1991. Detection of genes for enterotoxins, exfoliative toxins, and toxic shock syndrome toxin 1 in Staphylococcus aureus by the polymerase chain reaction. J. Clin. Microbiol. 29:426-430.

Karahan, M., M. N. Açik, and B. Cetinkaya. 2009. Investigation of toxin genes by polymerase chain reaction in Staphylococcus aureus strains isolated from bovine mastitis in Turkey. Foodborne Pathog. Dis. 6:1029-1035. https://doi.org/10.1089/fpd.2009.0304.

Katsuda, K., E. Hata, H. Kobayashi, M. Kohmoto, K. Kawashima, H. Tsunemitsu, and M. Eguchi. 2005. Molecular typing of Staphylococcus aureus isolated from bovine mastitic milk on the basis of toxin genes and coagulase gene polymorphisms. Vet. Microbiol. 105:301-305. https://doi.org/10.1016/j.vetmic.2004.12.004.

Li, Y., R. Zhao, X. Zhang, Q. Han, X. Qian, G. Gu, J. Shi, and J. Xu. 2015. Prevalence of enterotoxin genes and spa genotypes of methicillin-resistant Staphylococcus aureus from a tertiary care hospital in China. J. Clin. Diagn. Res. 9:DC11-DC14. https://doi. org/10.7860/JCDR/2015/12090.5990.

Løvseth, A., S. Loncarevic, and K. G. Berdal. 2004. Modified multiplex PCR method for detection of pyrogenic exotoxin genes in staphylococcal isolates. J. Clin. Microbiol. 42:3869-3872. https:// doi.org/10.1128/JCM.42.8.3869-3872.2004.

Lundberg, A., A. Aspán, A. Nyman, H. E. Unnerstad, and K. P. Waller. 2014. Associations between bacterial genotype and outcome of bovine clinical Staphylococcus aureus mastitis. Acta Vet. Scand. 56:2. https://doi.org/10.1186/1751-0147-56-2.

Malachowa, N., and F. R. DeLeo. 2010. Mobile genetic elements of Staphylococcus aureus. Cell. Mol. Life Sci. 67:3057-3071. https:// doi.org/10.1007/s00018-010-0389-4.

McClure, J. A., J. M. Conly, V. Lau, S. Elsayed, T. Louie, W. Hutchins, and K. Zhang. 2006. Novel multiplex PCR assay for detection of the staphylococcal virulence marker Panton-Valentine leukocidin genes and simultaneous discrimination of methicillin-susceptible from -resistant staphylococci. J. Clin. Microbiol. 44:1141-1144. https://doi.org/10.1128/JCM.44.3.1141-1144.2006.

McMillan, K., S. C. Moore, C. M. McAuley, N. Fegan, and E. M. Fox. 2016. Characterization of Staphylococcus aureus isolates from raw milk sources in Victoria, Australia. BMC Microbiol. 16:169. https://doi.org/10.1186/s12866-016-0789-1.

Mehrotra, M., G. Wang, and W. M. Johnson. 2000. Multiplex PCR for detection of genes for Staphylococcus aureus enterotoxins, exfoliative toxins, toxic shock syndrome toxin 1 , and methicillin resistance. J. Clin. Microbiol. 38:1032-1035.

Nazari, R., H. Godarzi, F. Rahimi Baghi, and M. Moeinrad. 2014. Enterotoxin gene profiles among Staphylococcus aureus isolated from raw milk. Iran. J. Vet. Res. 15:409-412.

Oliveira, L., A. C. Rodrigues, C. Hulland, and P. L. Ruegg. 2011. Enterotoxin production, enterotoxin gene distribution, and genetic diversity of Staphylococcus aureus recovered from milk of cows with subclinical mastitis. Am. J. Vet. Res. 72:1361-1368. https://doi. org/10.2460/ajvr.72.10.1361.

Omoe, K., D.-L. Hu, H. Takahashi-Omoe, A. Nakane, and K. Shinagawa. 2005. Comprehensive analysis of classical and newly described staphylococcal superantigenic toxin genes in Staphylococcus aureus isolates. FEMS Microbiol. Lett. 246:191-198. https:// doi.org/10.1016/j.femsle.2005.04.007.

Ote, I., B. Taminiau, J.-N. Duprez, I. Dizier, and J. G. Mainil. 2011. Genotypic characterization by polymerase chain reaction of Staphylococcus aureus isolates associated with bovine mastitis. Vet. Microbiol. 153:285-292. https://doi.org/10.1016/j. vetmic.2011.05.042

Parisi, A., M. Caruso, G. Normanno, L. Latorre, R. Sottili, A. Miccolupo, R. Fraccalvieri, and G. Santagada. 2016. Prevalence, antimi- 
crobial susceptibility and molecular typing of methicillin-resistant Staphylococcus aureus (MRSA) in bulk tank milk from southern Italy. Food Microbiol. 58:36-42. https://doi.org/10.1016/j. fm.2016.03.004

Piccinini, R., V. Borromeo, and A. Zecconi. 2010. Relationship between $S$. aureus gene pattern and dairy herd mastitis prevalence. Vet. Microbiol. 145:100-105. https://doi.org/10.1016/j. vetmic.2010.03.005.

Pinheiro, L., C. I. Brito, A. de Oliveira, P. Y. F. Martins, V. C. Pereira, and M. de L. R. de S. da Cunha. 2015. Staphylococcus epidermidis and Staphylococcus haemolyticus: Molecular detection of cytotoxin and enterotoxin genes. Toxins (Basel) 7:3688-3699. https://doi.org/10.3390/toxins7093688.

Podkowik, M., K. S. Seo, J. Schubert, I. Tolo, D. A. Robinson, J. Bania, and J. Bystron. 2016. Genotype and enterotoxigenicity of Staphylococcus epidermidis isolate from ready to eat meat products. Int. J. Food Microbiol. 229:52-59. https://doi.org/10.1016/j. ijfoodmicro.2016.04.013.

Reyes-Robles, T., A. Lubkin, F. Alonzo, D. B. Lacy, and V. J. Torres. 2016. Exploiting dominant-negative toxins to combat Staphylococcus aureus pathogenesis. EMBO Rep. 17:428-440. https://doi. org/10.15252/embr.201540994.

Sabouni, F., S. Mahmoudi, A. Bahador, B. Pourakbari, R. H. Sadeghi, M. T. H. Ashtiani, B. Nikmanesh, and S. Mamishi. 2014. Virulence factors of Staphylococcus aureus isolates in an iranian referral children's hospital. Osong Public Health Res. Perspect. 5:96-100. https://doi.org/10.1016/j.phrp.2014.03.002.

Sergeev, N., D. Volokhov, V. Chizhikov, and A. Rasooly. 2004. Simultaneous analysis of multiple staphylococcal enterotoxin genes by an oligonucleotide microarray assay. J. Clin. Microbiol. 42:2134-2143.

Shariati, L., M. Validi, A. M. Hasheminia, R. Ghasemikhah, F. Kianpour, A. Karimi, M. R. Nafisi, and M. A. Tabatabaiefar. 2016.
Staphylococcus aureus isolates carrying Panton-Valentine leucocidin genes: Their frequency, antimicrobial patterns, and association with infectious disease in Shahrekord city, Southwest Iran. Jundishapur J. Microbiol. 9:e28291. https://doi.org/10.5812/jjm.28291.

Silva, N. C. C., F. F. Guimarães, M. P. Manzi, P. E. Budri, E. GómezSanz, D. Benito, H. Langoni, V. L. M. Rall, and C. Torres. 2013 Molecular characterization and clonal diversity of methicillinsusceptible Staphylococcus aureus in milk of cows with mastitis in Brazil. J. Dairy Sci. 96:6856-6862. https://doi.org/10.3168/ jds.2013-6719.

Suzuki, Y., M. Kobayashi, S. Matsushita, S. Uehara, R. Kato, Y. Sato'o, H. K. Ono, K. Sadamasu, A. Kai, and Y. Kamata. 2015. Detection of the staphylococcal enterotoxin D-like gene from staphylococcal food poisoning isolates over the last two decades in Tokyo. J. Vet. Med. Sci. 77:905-911. https://doi.org/10.1292/ jvms.15-0028.

Vimercati, C., P. Cremonesi, B. Castiglioni, G. Pisoni, P. J. Boettcher, A. Stella, G. Vicenzoni, and P. Moroni. 2006. Molecular typing of Staphylococcus aureus isolated from cows, goats and sheep with intramammary infections on the basis of gene polymorphisms and toxins genes. J. Vet. Med. B Infect. Dis. Vet. Public Health 53:423-428. https://doi.org/10.1111/j.1439-0450.2006.00980.x.

Wang, D., L. Zhang, X. Zhou, Y. He, C. Yong, M. Shen, O. Szenci, and B. Han. 2016. Antimicrobial susceptibility, virulence genes, and randomly amplified polymorphic DNA analysis of Staphylococcus aureus recovered from bovine mastitis in Ningxia, China. J. Dairy Sci. 99:9560-9569. https://doi.org/10.3168/jds.2016-11625.

Xu, J., X. Tan, X. Zhang, X. Xia, and H. Sun. 2015. The diversities of staphylococcal species, virulence and antibiotic resistance genes in the subclinical mastitis milk from a single Chinese cow herd. Microb. Pathog. 88:29-38. https://doi.org/10.1016/j. micpath.2015.08.004. 